\begin{abstract}
How do Black women engulf themselves in the politics of being and becoming through everyday existence, aesthetics and media practices in creative, pleasurable, diasporic and resistant ways? How are global power relations including the hegemony of North America, Eurocentrism, antiBlackness and sexism implicated in this? We consider such questions in relation to Black women's media and aesthetic practices, and their related scholarship through an examination of the Ghana-based web series An African City. In doing so, we echo calls for the decentering of media and communication studies rooted in white and Western perspectives but positioned as "universal.” We explore Black women's experiences (in Britain, the U.S., Ghana and Nigeria) as active producers in their communities in different continents; beyond the dominant epistemological hierarchy of whiteness in contrast with Blackness. Framing visual communication as a community-based source of self-expression, we emphasize the liberatory possibilities of aesthetics (fashion and screen depictions) for Black women, while tarrying with how capitalism constrains such radical potential.
\end{abstract}

Keywords: Aesthetics, African Media, Black Feminism, Black Women, Diaspora, Fashion 


\section{An African City: Black Women's Creativity, Pleasure, Diasporic (Dis)connections and Resistance Through Aesthetic and Media Practices and Scholarship}

\section{Introduction}

Bolstered by the work of Black scholars, African media studies and "\#CommunicationSoWhite" critiques about the structural dominance of whiteness within academia (Chakravartty, Kuo, Grubbs, \& McIlwain, 2018), we refuse to focus on white and "Western" experiences that are commonly uncritically positioned as "universal" (Abah, 2019; Adejunmobi, 2016; Martin, 2019). Relatedly, we contribute to and reiterate calls to challenge homogenizing conceptualizations of Black people's lives which do not meaningfully recognize diasporic differences across continents. After all, "Identity formation, the sense of being an embodied, located individual, does not occur in isolation from within a mono-logic of cultural development and formation" (Young, 2000, p. 45). Hence, we draw on our individual and collaborative research (Osei, 2019; Sobande, 2017; Sobande, Fearfull, \& Brownlie, 2019) to contribute to dialogue concerning the interrelated hegemony of North America, Eurocentrism, anti-Blackness, sexism and its implications in Black women's media and aesthetic practices, as well as related scholarship.

Based on our conviction in "the importance of Black women telling their own stories" (Bobo, 2001, p. xvii) to each other, we think through, and, with, the words and experiences of Black women in Africa, Europe and North America. We primarily investigate the meaning of Ghanaian diasporic fashion identity in Accra, London and Washington, D.C., through the lens of the Ghana-based web series An African City, in order to explore the media experiences of Black women in Britain. However, we also incorporate autoethnographic reflections (Boylorn, 2006) 
AN AFRICAN CITY: BLACK WOMEN'S CREATIVITY

and wrestle with contradictions inherent to this article, namely, our positions as Black women who are simultaneously oppressed and structurally dominant in ways connected to race, gender, class and global power dynamics.

Our article is inspired by writers who describe the politics of pleasure and feeling good (Brown, 2019), as well as Lu \& Steele's (2019) vital notion of joy in Black oral culture online; they account for how joy can be a form of resistance among Black people who live in a world where their proximity to death is palpable due to white supremacy. In the sections that follow, we first appraise the "field/disciplines" of media, communication and cultural studies and consider the significant contributions of Black women to these areas. Then we discuss material cultural work related to aspects of Black women's media production, engagement and aesthetic practices. Overall, we reflect on Black women's experiences (in Britain, the U.S., Ghana and Nigeria) as transnational narrators of their own stories, including forms of diasporic solidarity (Hall, 2019) and (dis)connections shaped by media and aesthetics. In turn, we yield insight into how Black women's active engagement with fashion and media can manifest as political declarations of self-portraiture that struggle against and within capitalist structures.

\section{Beyond whiteness and Anglo-American perspectives: Black women, Black feminism and media}

Chakravartty et al.'s (2018) ground-breaking “\#CommunicationSoWhite” article clearly outlines how "[r]acial inequalities and the colonial legacies of White supremacy permeate scholarly and public discussions today" (p. 254). Such work highlights "an ongoing movement to decenter White masculinity as the normative core of scholarly inquiry" (ibid.). Aligned with the "\#CommunicationSoWhite" ethos, we do not engage with white-centered scholarship that is 
AN AFRICAN CITY: BLACK WOMEN'S CREATIVITY

typically framed as "canonical" and "universal" despite a narrow and culturally specific perspective that fails to meaningfully address issues concerning race and racism (Martin, 2019).

We recognize the transformative capabilities of cultural expression through visual culture, by reckoning with "the everyday labor that black women have mastered since captivity carrying loss with dignity, mourning in plain sight, and at the same time, refusing to capitulate to the mundane regularity of black death" (Campt, 2019, p. 85). Black people's choice to center Black lives and knowledge in media and aesthetics studies should not be construed as creating and crafting work merely in response to whiteness. Rather, such work on Black life and knowledge can exemplify how Black creativity and cultural production flourishes, despite, instead of as a reaction to, hegemonic whiteness.

In the words of scholar Moradewun Adejunmobi (2016, p. 125), there is "relative detachment of African media studies research from the discipline of media studies in North America.” Moreover, Aida Opoku-Mensah's (2010) work on African feminist media studies shows how facets of media and communication studies, such as the absence and presence of feminist approaches, varies across different geo-cultural settings. Since Opoku-Mensah's (ibid) major contribution, the area of African feminist media studies has expanded and, yet, is still treated as peripheral in comparison to Anglo-American work.

The media representation and experiences of Black women has been a source of crucial scholarship, particularly work led by Black women which explores different celebrity depictions (Chatman, 2015; Jackson, 2014; Joseph, 2018), examines the relationship between algorithms and racism (Noble, 2018), and identifies "symbolically devastating treatments of Black womanhood" (Coleman, 2011, p. 35) in Western media. Focusing on contexts which are commonly depicted in media in the Global North via colonialist notions of African inferiority 
AN AFRICAN CITY: BLACK WOMEN'S CREATIVITY

(Bonsu, 2009), researchers such as Adedayo Ladigbolu Abah (2008, p. 335) examine how the Nollywood culture industry in Nigeria has been a site of "the struggles of African women for opportunities for equality, self-actualization, and self-determination.” As well as accounting for how Black women can exert their agency through the Nollywood industry, Abah (2008) outlines how they are also portrayed on-screen in restrictive ways.

The Nollywood industry generates television and film content that tends to feature predominantly Black casts and differs to North American and European media industry contexts in many ways. Still, because of its rising popularity globally, paired with sexism and the impact of colonialism on Nigeria, depictions of Black women in Nollywood are not exempt from the influence of white patriarchal capitalist supremacy and structural colorism. Despite Nollywood culture having received an increasing amount of scholarly attention (Abah, 2019; Adejunmobi, 2016), many other aspects of African media and cultural production are comparatively scarcely discussed amidst related studies. For this reason, our article considers elements of Ghanaian media and aesthetic practices.

The topic of visuality and aesthetics has been central to Black women's generative work on (re)imagining life and the politics of refusal as Black people (Benjamin, 2019; Campt, 2019). In particular, these regenerative mechanisms allow us to further reimagine methodological approaches through aesthetic practices. From making GIFs to reflect on and bear witness to Black people's experiences of racial surveillance (Jones, 2019), to methodological approaches that include analysis of clothing choices and style (Johnson, 2017; Tulloch, 2016), Black women's aesthetic practices and studies based on methodologies that incorporate visual culture involve forms of creativity, pleasure and resistance-including media activity (Clark, 2014; Mohammed, 2019; Williams, 2016). 
AN AFRICAN CITY: BLACK WOMEN'S CREATIVITY

Research and writing embedded in Black feminist thought and Black women's knowledge and creativity offers insights related to the intricacies of oppressive interactions, institutions and capitalist infrastructures that Black women encounter (Aidoo, 1977; Mohammed, 2019; Opoku-Mensah, 2010; Salo \& Mama, 2001; Young, 2000). Therefore, we draw on Black women's work on navigating interlocking structural oppression that is "as old as empires" (Aidoo 1977, p. 87), such as through Black women forming "an interpretive community” (Bobo, 1995, p. 27) in ways that are often obscured as part of essentializing and discriminatory media discourse about them (Opoku-Mensah, 2010; Smith-Shomade, 2002).

What does it mean to do media and aesthetic studies work that centers Black women, as individuals who are both simultaneously oppressed due to intersecting anti-Black racism and sexism, and structurally dominant due to classed experiences and global hierarchies that often position scholarship stemming from the U.S. and Britain as being the most "authoritative" in academia? Why are Black women in different continents using media and aesthetic practices in creative, pleasurable, diasporic and resistant ways? Guided by these questions and centered on discussion about the web series An African City and its viewers, we explore Black women's transnational negotiation of issues related to cultural authenticity and agency, through the embodied practice of fashion communication and other forms of aesthetic and visual expression (Bakare-Yusuf, 2006; Ford, 2015).

We take heed of calls for "a decentering of media theories based entirely on the experience of Western media to the exclusion of material derived from empirical studies of media in the varied locations of the global South" (Adejunmobi, 2016, p. 133). As such, we oscillate between the words of Black women in different parts of the world (Africa, North 
AN AFRICAN CITY: BLACK WOMEN'S CREATIVITY

America and Europe); unpacking similarities, differences and diasporic (dis)connections between their experiences as creatives, scholars, and architects of their aesthetic image and imagination.

\section{Researcher background and approach}

We understand Black feminist autoethnographic methodologies as being based on Black women's efforts “to return to a belief in the power of our productivity informed by a rigorous inquiry into our lived always already intersectional struggles for liberation" (Brown-Vincent, 2019, p. 114). Accordingly, as part of this article we reflect on how our friendship, specificallyBlack sisterhood - is a part of what we refer to as “Black women's creativity, pleasure, diasporic (dis)connections and resistance through aesthetic and media practices and scholarship". In turn, we acknowledge the complexities of Black women's lives, rather than upholding their objectification and spectacularization by non-Black people who "examine" them with the “"freedom' to be nominally invested in their subjects of inquiry” (Brown-Vincent, 2019, p. 114).

We are both Black women of West African descent, each with a parent who migrated from Africa (Nigeria and Ghana) to either Britain or the US. We recognize that we are Black women tethered to Anglo-American identities and institutions, which restricts the radical potential of our work because it emerges from our position as both structurally marginalized and geographically advantaged. Therefore, while we critique the hegemony of Anglo-American scholarship, we do so from a place of relative privilege, even from within scholarly spaces that are critical of the interdependency of racism, sexism, and colonialism.

Part of the politics of refusal (Campt, 2019) that informs our article is the refusal to perform any illusory type of "objectivity" and personal distance between ourselves and our research. The notion of objectivity is arguably based upon white Eurocentric masculinist 
AN AFRICAN CITY: BLACK WOMEN'S CREATIVITY

conceptualizations of knowledge production, which are dismissive of knowledge anchored in the lived experiences of Black people (Collins, 2000), and upholds an assumed irreconcilable distinction between what is referred to as data and knowledge, and what is referred to as anecdotal. Consequently, we use first-person pronouns and reflect on the scholarly and personal path(s) that led us to this point, since first meeting each other in 2017 as early-stage PhD researchers at Black Film, British Cinema - a conference in Britain in 2017:

Beyond bonding over discovering that we were born days apart, we have found a kinship constructed by the contours of our different Black diasporic identities and shared interest in and experiences of Black women's aesthetic and media practices; from fashion and art production, to watching online web-series and YouTube content. We have reflected on what it can mean to be Black in different parts of North America, Britain and Africa. We have bemoaned the trivialization of Black fashion and creativity, as well as assumptions that such practices are apolitical and lack the potential to be resistant in nature. We have discussed the insidiousness of colorism and how societally favored on-screen depictions of light-skinned and "mixed" Black women compare with dehumanizing representations of dark-skinned Black women. We have worried about different challenges that we face, including institutional pressures to produce, generate and be present(ed), despite dealing with health issues that few people care to know about. We have both been confronted by iterations of structural oppression and obstruction throughout the course of our academic experiences; from peer review comments that deny the reality of Black women's lives, to combative responses to our decisions to center Black women in our work. 
AN AFRICAN CITY: BLACK WOMEN'S CREATIVITY

Nevertheless, together we explore our different understandings and experiences of Blackness and being Black women, while recognizing the limited nature of these as they are predominantly located within "Western" lived realities. Our research on Black women's media and aesthetic practices is primarily based on semi-structured in-depth interviews with Black women, accompanied by autoethnographic reflections (including in poetic and photographic form) and analysis of media practices. We now turn to some of our research findings on how Black women use various forms of aesthetic self-expression and/or interpret such forms of visual communication as empowering and emancipatory, and in ways influenced by specific dimensions of Black diasporic life.

\section{An African City: Marketplace dynamics of Ghanaian fashion}

It is crucial to understand the significance of the quintessential mashup between African and Western materiality presented on the Accra-based web series An African City (which debuted on YouTube in 2014):

I had never seen a specific cultural representation of Ghana packaged as glamorous and fashion-forward in television before binge-watching season 1 and season 2 of An African

City in a single weekend in 2016 at home in Washington, D.C. Set in Accra, the capital of Ghana, the series featured cutaway shots showcasing heritage sites, cultural landmarks, bars and restaurants, and different buildings that threw me off of my anthropological understandings of what constituted "traditional" and "authentic" Ghanaian cultural life. In essence, the optics of the series disrupted my colonial interpretations of Black Africa 
AN AFRICAN CITY: BLACK WOMEN'S CREATIVITY

that I was exposed to growing up. (Krys Osei, 2019)

Acknowledging and analyzing the aesthetics offered in An African City sheds light on the contemporary Americanization of the African fashion industry and opens new pathways for understanding how exploitative partnerships with Western investors and exorbitant import tariffs continue to limit opportunities for African fashion designers to launch their collections internationally (Ford, 2015, p. 188). This mashup operates as a celebratory tool of independence, against the backdrop of Dutch fashion imperialism that relies on the commodification of Black African women in mainstream advertising and marketing campaigns.

Nicole Amarteifio, a Ghanaian-born American, created An African City to talk back to the single story of Africa that she overwhelmingly consumed through news and current affairs outlets as a young girl growing up in Westchester, New York. The show, while fictionalized, is directly inspired by one of her favorite television programs: Sex and the City; however, the fundamental premise of the series is based on her personal experience of resettling in Ghana as an adult diasporic woman. The elegant and opulent narratives about West African fashion pay homage to the legacy of glamorous Ghanaian women in her life - her mother and stylish aunties - who encouraged her to pick up a pen and become a storyteller:

From a young age, I looked to non-verbal declarations of presence after growing tired of explaining my existence to those committed to misunderstanding my identity. I looked to curate my personal style imprint: from taking the lead in putting up Christmas decorations in our family home to appointing myself as my mother's official personal stylist. Indeed, consuming my heritage through the language of fashion depicted within 
AN AFRICAN CITY: BLACK WOMEN'S CREATIVITY

An African City was a transformative event driven by the expansive emotion of finally associating my heritage with joy. (Krys Osei, 2019)

Fashion and associated digital media and communication has provided an alternative space for Black African women cultural producers - who operate on both margins of the African and Western commercialized cultural industries - to bypass their circumscribed style geographies that are engaged in a continuous battle against domination stemming from the entanglements of white supremacist patriarchal capitalism and connected Western hegemony (McKittrick, 2006).

The narrative of fashion within An African City is encapsulated through luxury and cinematic depictions of vivid palettes of African wax print fashion - a globally popular aesthetic symbol that represents the resilience and influence of African fashion in the global marketplace. Nicole Amarteifio, creator of An African City, mirrored these sentiments throughout an interview conducted with her in January 2018 in Accra as part of research that underpins our article. She was especially reflexive on her intentional motivations behind creating the series as a means to challenge the iconicity of hegemonic Western media outlets:

Am I doing this to prove to the West that we are human and that we deserve dignity? I don't want that to be my reason. Granted, that's probably how it started [...] but now I also think it's for us. Um...you know? It's for that six-year-old girl who's Ghanaian and Black and living in Westchester, New York and turns on CNN and hears this negative report about Africa, but she has this other representation. She has these beautiful women...all shades of brown...in beautiful African attire. Yeah, she has that representation to also look up to as well. 
AN AFRICAN CITY: BLACK WOMEN'S CREATIVITY

An African City presents a visual tapestry of African wax prints featuring the Dutch wax powerhouse brand, Vlisco, headquartered in The Netherlands, but made famous in West and Central Africa by local consumers and fashion designers - further demonstrating the interconnected relationship between fashion, global capitalism and the lingering ghosts of colonialism that persist within community-based attempts to aesthetically dismantle frameworks of dispossession.

The notion of fashionable "invented African traditions" (Sylvanus, 2013, p. 34) cannot be separated from extensive Dutch colonial textile trade routes within West and Central Africa. This legacy of interwoven European and African material aesthetic cultural synchronization continues to solidify Vlisco's presence as an original, authentic reflection and portrait of African luxury (Bruggeman, 2017, p. 201); in other words, Vlisco is "for the Ghanaian, Nigerian, Beninoise or Congolese woman what Hermes or Louis Vuitton is for the European" (Cronberg. 2012, p. 313).

From glossy print advertisements to promotional broadcast campaigns, the glamorous spectacle of the brand is crafted and sustained by (re)presenting and (re)packaging the marketization of luxurious Black African womanhood (Delhaye \& Woets, 2015, p. 81). This process of (re)presentation contributes to the normalization of the emergence of non-Western Black femininities - often hidden by the aesthetic colonial artefact of white female iconicity that propels the growth of upscale commercial fashion markets (Coly, 2019; Tate, 2009, p. 53) - such marketing tactics raise issues surrounding the aesthetic commodification of Black African women's style for Dutch profit maximization, which mirrors colonial and postcolonial discourses committed to viewing the bodies of Black African women as transactional commodities (Coly, 2015). 
AN AFRICAN CITY: BLACK WOMEN'S CREATIVITY

An African City's elaborate aestheticization and stylish flair can be interpreted as a "homegrown" attempt to overturn and reclaim the colonial, racialized, gendered, and classed politics of fashion and embodiment by (re)appropriating selective tenets of perceived white female iconicity that contributed towards the international success of the production, distribution and reception of Sex and the City. At the same time, An African City situates its aesthetic presence within the context of social and political commentary concerning real-time issues impacting Ghana, such as "Dumsor" - "an amalgamation of the Twi words for "on" and "off"- a twenty-first century colloquialism created to describe Ghana's power sharing situation (Asare, 2018 , p. 189) that speaks to the historical and contemporary epidemic of unpredictable blackouts. An African City further addresses social and political themes ranging from real estate and the complexities of securing Ghana home loans, career limitations, the gender pay gap, and the feminist and sexual politics of Black diasporic women across geographic time and space.

Black women's proactive use of fashion, visual communication and media aid their efforts to challenge contemporary imperialist, racist and sexist projects, but are just one of many ways in which they experience pleasure. Although our work focuses on the contemporary aesthetic and media practices of Black women, we recognize the long and rich history of related experiences and activities; including the role of hairstyles in secret messaging systems between enslaved Black people (Byrd \& Tharps, 2002), and the power of Black women documenting their lives from behind the lens of a camera, through digital devices (Mohammed, 2019; Williams, 2016) and as part of Black Twitter (Clark, 2014). In response to recognition that "it is critical that we determine the means by which programming is created and directed at women while remaining committed to meaningful cultural specificity" (Warner, 2019, p. 168), the following section elaborates on the experiences of Black women in different parts of the world. 
AN AFRICAN CITY: BLACK WOMEN'S CREATIVITY

\section{Black women's creativity, pleasure and resistance through African media and aesthetics}

The interviews with Ghanaian women producers and audience viewers in Accra remain the most transformative element of my fieldwork experience. It was challenging to (re)define the meaning of Ghanaian women audience viewers in Accra due to intergenerational patterns of family migration. These women expanded my understandings of postcolonial ethnicity, nationality, citizenship and the proliferation of anti-Black African womanhood through layered, Western and non-Western lived experiences embodied across the African continent and abroad. I learned more about myself, the interconnected relationship between fashion and colonialism in Northern Africa and Latin America, following two memorable interviews with an Afro-Colombian fashion designer of Ghanaian and Jamaican parentage, and a Ghanaian fashion model raised in Libya who binge watched episodes of An African City at internet cafes as a means to advocate for herself and entertainment career ambitions as a diasporic returnee. (Krys Osei, 2019)

Certain aesthetic practices and media content engaged with by Black girls and women enable them to delight in elements of African culture, even when living outside of the continent. Despite the deficiencies of much of the media they encounter, the experiences of Black women are not exclusively defined by structural oppression that they face. Rather, such practices and experiences around media include forms of self-expression, creativity, pleasure, joy, and ingenuity (Benjamin, 2019; Clark, 2014; Gray, 2016; Lu \& Steele, 2019; Steele, 2017), even as 
AN AFRICAN CITY: BLACK WOMEN'S CREATIVITY

these are often treated as mere consumable commodities within mainstream media and cultural spheres in predominantly white societies.

Certainly, given the capitalist infrastructures that Black women's media and aesthetic practices and scholarship often exist within, one might wonder if the resistant potential of such activities remains largely constrained. For example, despite social media having contributed to the consciousness-raising efforts of Black diasporic women, including those who have turned to the internet in pursuit of what Okra referred to as "decolonization of the mind," these online contexts still exist within a consumer culture bolstered by a market logic that feeds the commodification and spectacularization of Black lives and Black pain (Sobande, 2019).

Nevertheless, there are many examples of how aesthetic practices and media are incorporated into Black women's resistant politics and expressions of self-affirmation, from afro hair becoming a symbol of the Black is Beautiful movement which developed from the 1960s onwards (Byrd \& Tharps, 2002), to the collective, self-publishing and archiving of Black women's writing (Bryan, Dadzie, \& Scafe, 1985), and their use of digital media to protest social injustices (Clark, 2014; Mohammed, 2019; Nyabola, 2018b);

In the words of community-based researcher and healing practitioner Naya Jones (2019, p. 1078): “Centering Black emotions, means grappling with (mis)representations of Black affective responses as always lacking, excessive, unintelligible, and/or non-existent." Despite Black women often being depicted and discussed in derogatory ways in mainstream media and public spheres that are punctuated by patriarchal whiteness, some such women have "invented their own unique aesthetic expressions" (Bobo 2001, p. xv), as "Their lifestories are not just tales of stoic endurance or mute acceptance" (ibid.). 
AN AFRICAN CITY: BLACK WOMEN'S CREATIVITY

The women who were interviewed for the research related to An African City identified themselves by naming ethnic and linguistic groups and commonly referenced their parents' hometowns as their origin, as opposed to social class ranking. They frequently used picturesque nature descriptions and referenced aromatic fragrances as a means to topographically map - in the face of arbitrary geopolitical and colonial boundaries - where in "Ghana" their family lineage originates. The composition of their identities stems from a range of botanical gardens, cocoa farms, evergreen mountain ranges with unpredictable meteorological weather patterns, their great-great-grandfather's oceanfront fishing village that borders the coast of Togo, alongside skilled textile practitioners, artisans and weavers in the rural Ashanti Region. Their detailed explanations of who they are were unanticipated by us as researchers:

Oftentimes I was met with long periods of silence as the women paused to collect their thoughts on the following straightforward (or so I thought) informal introductory research question: "Where are you from in Ghana?" - I'd openly communicated my limited knowledge on rural, regional, human and cultural West African geography, as my ignorance expected participant responses to name the largest metropolitan cities in Ghana-including Accra, Kumasi, Cape Coast and Sekondi-Takoradi as their home. It was an enriching cultural exchange to listen to Ghanaian women talk back to legacies that continue to flatten their existence. The assertion of who they are is challenged even before they open their mouths to speak. (Krys Osei, 2019)

Through embellished fashion communication, An African City is a rare occurrence that offers some Black Ghanaian women the ability to narrate their own lives through a well-intentioned 
AN AFRICAN CITY: BLACK WOMEN'S CREATIVITY

aesthetic presentation. One theme that emerges across our individual research projects concerning Black women's media practices is that Black women's experiences of viewing and producing media depictions of Black women, while living in Ghana and Nigeria, can notably differ from their experiences when living in Britain. In part, these differences can be shaped by the specific way that Black identities are minoritized in predominantly white societies (Bryan et al., 1985), where Black women may experience feelings of hypervisibility and invisibility distinct from how their identities are felt and responded to in predominantly Black countries. In addition, such experiences can be impacted by how Western media depict Africa(ns) in oppressive ways (Nyabola, 2014) influenced by British colonialism and the associated global power of Britain.

Related encounters are captured by the words of an interview participant based in Britain, who chose the pseudonym Okra and spoke of joyous feelings she experienced as a young child encountering media images of Black women when living in Nigeria:

Well everyone is Black [in Nigeria] ...so it wasn't a thing [specifically trying to find media images of Black women] you look at TV differently 'cause you're not trying to pick out the Black person, you're just watching TV ...Kuti's dancers! ...aw! [expression of delight], it's the colors and their outfits because they were so colorful, and they had this face painting that the Yorùbá, it's like a ritualistic kind of enchantment. 'Cause I remember being... about three... and my dad has his friends round, it's raining outside and the rain is hitting the tin roof so it's making that 
AN AFRICAN CITY: BLACK WOMEN'S CREATIVITY

rattling sound and we're in the little porch area... and his three friends are sitting out and we're watching on this tiny TV...Fela Kuti and the girls dancing...Girls? [Okra corrects herself] women! And he was drinking Guinness and he had it on his moustache, and I remember drinking out the Guinness 'cause I used to like that...that is one of my earliest really happy images...is watching the dancers and watching my dad and his friends.

As is observed by writer, humanitarian advocate, and political analyst Nanjala Nyabola (2018a), despite "appeals to a unitary black identity," at times, media depictions of Black people take the form of Western popular culture (re)presentations which are intended for a Western audience. Unlike the pleasure that Okra associates with some depictions of Black women in Nigerian media, and reminiscing about them, she spoke of many depictions of Black people in Britain being so offensive and based upon a white imperialist gaze that they negatively impacted her as a child. Nevertheless, when speaking fondly of the abundance of media depictions of Black women in Nigeria in comparison to Britain, consistent with the work of Abah (2008), Okra recognized that such representations in Nigeria include derogatory sexist and misogynistic portrayals:

There were definitely stereotypes...dramatic over-characterizations...so there would be the mummy that bossed everyone around and was always cooking and gossiping in everyone's business. 
AN AFRICAN CITY: BLACK WOMEN'S CREATIVITY

Given the impact of globalization and rise in transnational media and communication flows since Okra was a child in Nigeria around thirty years ago, a Western audience and structurally white gaze is increasingly courted as part of the production of certain types of media in Nigeria. For individuals such as Okra, the pleasure that they may derive from various media depictions of Black women and their embodied aesthetic, is not simply related to seeing a Black woman on screen. Rather, it can be strongly connected to media representations that portray elements of specific Black African cultures and diasporic experiences; in this case, with a focus on Nigerian aesthetics, and particularly, Yorùbá culture. How Okra experienced watching Fela Kuti's dancers as a child was a culturally specific moment of racialized and gendered memory, meaning-making and pleasure.

Another interview participant, who chose the pseudonym Ola and who also moved to Britain from Nigeria as a child, spoke about some similar experiences. Ola reflected on how much she enjoys seeing famous Black women in Britain wearing African fashion, including when seeing Michaela Coel's dress at the BAFTA ceremony in 2016, which Coel's mother made for her. Ola said:

I'd like to run my own business. I'd like to own my own clothing line, which is what I'm hoping to work towards this summer. Michaela Coel...yeah, the Kente...that was gorgeous and I loved the fact that she did that. You don't get a lot of celebrities that want to wear like...African materials to such prestigious events, like the BAFTAs...so it was great that she wanted to do that and was representing...yeah, I'd definitely like to do something that incorporates my own cultural background, using Nigerian materials 
AN AFRICAN CITY: BLACK WOMEN'S CREATIVITY

and stuff like that.

Although the experiences that Okra and Ola shared indicate pleasure in engaging with African media content and aesthetics, there was not an explicit connection to Black feminist or resistant sentiments. However, the web series An African City presents its aestheticization and stylization as a counter-hegemonic tool which blurs the geographic binary separating Western and African fashion (Ogunyankin, 2016, p. 40). As the five women characters "insert and assert themselves into the global fashion world" (ibid.) through Ghanaian luxury brands, they loudly declare "their refusal to be dispossessed and rendered ungeographic in the cosmopolitan cartography of sartorial worldliness" (ibid.). Situating their style narratives as a form of levitation (Tulloch, 2016, p. 193)-in other words, "invisibly" rising above the demarcation lines of racism, sexism and xenophobia-their embodiment serves as a bold "declaration of Black feminine freedom" (ibid., p. 197).

During an interview in Accra with the principal wardrobe stylist for season two of $A n$ African City, Afua Rida spoke candidly about the transformative role fashion played in helping her navigate her dual Ghanaian and Lebanese heritage. Growing up in Ghana and further studying in Canada for university, witnessing the growth and expansion of Ghanaian fashion houses, women-led brands and social enterprises abroad served as key defining moments that inspired her to pursue a career in fashion styling, ultimately back home in Ghana:

I love how I can take what all the designers do and like, create magic with it... and around that time, Ghana was also kind of bubbling with upcoming new talent and the new school designers were coming up... and I was seeing what Christie Brown was doing, and 
AN AFRICAN CITY: BLACK WOMEN'S CREATIVITY

\begin{abstract}
Abrima Erwiah with Studio One Eighty Nine and Mina Evans, and I said: "Wow!" - like these girls are really doing something big, they are sitting on something very important... and then I realized that there weren't any stylists [like in Montreal] who I saw play an important part with the designers and dressmakers, so it was also around that time where I knew that I wanted to come back to Ghana, I knew that I wanted to help develop my country, so I said well, there you go...come back, start styling....and then it took off from there.
\end{abstract}

Afua was also passionate when describing the motivations behind exclusively sourcing and featuring Ghanaian and African fashion designers on the series:

Because...we gotta represent ourselves! Especially in Ghana, and I'm sure in other parts of the world that don't really have solid fashion magazines...South Africa is pretty good with their fashion magazines, and in Nigeria they're pretty good as well, but in Ghana we don't have solid fashion magazines... and when An African City started [in 2014], there wasn't even enough representation online...so yeah, An African City served that purpose to showcase these designers and put them on the map! And wave all the African flags high.

The curation and local assemblage of Ghanaian and African wardrobe on An African City was an intentional tool of strategic visibility (as discussed by those involved in it), in efforts to increase brand awareness to a global audience. However, women audience viewers in the Ghanaian 
AN AFRICAN CITY: BLACK WOMEN'S CREATIVITY

diaspora (in London, Accra and Washington, D.C.), expressed conflicting interpretations surrounding the narrative of fashion with regards to cultural authenticity.

When asked to express their thoughts on the political, resistant and self-empowering features of fashion and aesthetics represented on An African City, their individual responses illuminate nuances of what constitutes pleasure and resistance when imperial constructed notions of "dominant" and "peripheral" cultural hierarchies are at play. For instance, during an interview with 23-year-old Lily, an English-Ghanaian viewer in London, she expressed an incessant need for contemporary representations of Ghanaian womanhood to disassociate from Western ideals of femininity that center on outward appearance. When asked whether she considered An African City to be an empowering web series, she replied:

No...no. Like, empowering? Maybe in the sense of fashion...in the sense of most of them wearing natural hair...in the sense that they were women, women's empowerment. But I don't know, not in the sense of portraying the reality of Ghana... I just found it to be a bit...not fake, but just a bit too Westernized...so if it's too Westernized then I don't really find it empowering to be honest.

Meanwhile, Amaryllis, a 22-year-old Ghanaian-American viewer in Washington, D.C. celebrated the portrayal of Ghanaian women as glamorous and fashion-forward, and understood the positioning of luxury fashion as a matter of urgency. For her, the characters' meticulous presentation is a direct response to the hidden legacy of Black African women's aesthetic identity (Tulloch, 2016, p. 197), often clouded by flat depictions of otherness (hooks, 1992). When asked whether she found the series to be empowering, she exclaimed: 
AN AFRICAN CITY: BLACK WOMEN'S CREATIVITY

Oh, one thousand percent! Because I feel like usually African women...they're not shown like that, you know? I guess some may say: "Oh the women on the show are just promiscuous or something...” and I'm like no, they're just grown ass women, you know? With agency over their own bodies and they get to do what they want, as they so please, you know? And I saw nothing wrong with it. I was just like yes, live your life!

As is articulated by scholar Tanisha C. Ford (2015), historically, fashion has been used as a vehicle for social and political sites of activism throughout Black liberation movements around the globe. However, for Black African women, in particular, the performative element of selfexpression provides a unique and monumental way for them to negotiate their assigned raced, gendered, geographic and spatial parameters of inferiority (p. 166). Gardenia, a 36-year-old Ghanaian viewer in Accra expressed similar sentiments regarding the significance of An African City being set against the backdrop of postcolonial Ghana:

I think it was created to represent what the African woman goes through in Ghana but probably doesn't get the chance to talk about on a larger scale...so An African City for me represents all the different identities that need to be heard because of family pressures, peer pressure and societal pressures within a city where it's a hustle to get things done. 
AN AFRICAN CITY: BLACK WOMEN'S CREATIVITY

While it is seemingly impossible for one web series to fully depict and grasp the multi-layered experiences of Ghanaian womanhood, it is certainly necessary to expand beyond the essentialist framings of Western and African, too often categorized by notions of - or lack of - authenticity. Perhaps there is a need to revisit the towering existence of Vlisco and Dutch wax print in the West and Central African marketplace as accessible self-fashioning tools rooted in omnipresent, glorious, incandescent presence that reveal aesthetic practices that are part of experiences of pleasure and resistance within the boundless repository of Ghanaian diasporic Black femininities. From material contexts to online ones, Black women continue to forge and maintain spaces to express and push against their experiences of marginalization and reclaim creativity and joy via aesthetics and media; speaking to, through, and, with, specific understandings of African diasporic life.

\section{Conclusion}

There are many reasons why Black women in different continents use media and aesthetic practices in meaningful, creative, pleasurable and resistant ways. As our research on the myriad ways that An African City is meaningful elucidates, among such reasons is Black women's desire to express and explore their connections to specific African diasporic cultures and experiences, the nuances of which are often denied by universalizing notions of Blackness that are promulgated by scholarship that centers institutionally white and Western perspectives. More research related to the media and aesthetic practices and experiences of Black women in different geo-cultural contexts can further scholarly efforts to resist essentializing and homogenizing notions of Black womanhood and Black culture, which often dismiss the intricacies of different African diasporic experiences. 
AN AFRICAN CITY: BLACK WOMEN'S CREATIVITY

(Re)imagining Black women's lives outside of white supremacist and sexist oppressive power relations is not without its challenges but is worth pursuing. The resistant capacity of media and aesthetics scholarship about and by Black women, can be nurtured in ontological and epistemological foundations that decenter whiteness. That said, Black women's media and aesthetic practices and research need not be obviously or straightforwardly resistant to be meaningful and to matter. Our work contributes to scholarly conversations concerning creativity and joy as a source of Black resistance (Lu \& Steele, 2019) which can be embodied, aestheticized, and mediated in various ways shaped by globalization and transnationalism. While we remain critical of claims that reductively equate Black women's liberation with their consumer culture activities, we also maintain the position that Black women's marketplace and media choices and production can be political, and, at times, involve struggling against their/our oppression. 
AN AFRICAN CITY: BLACK WOMEN'S CREATIVITY

\section{References}

Abah, A. L. (2008). One step forward, two steps backward: African women in Nigerian videofilm. Communication, Culture \& Critique, 1(4), 335-357. doi:10.1111/j.17539137.2008.00027.x

Abah, A. L. (2019). NollywoodUSA: Opportunities and challenges in forging a Pan-African storytelling and identity. In O.O. Banjo (Eds.), Media across the African diaspora: Content, audiences, and influence (pp. 98-121). New York: Routledge.

Adejunmobi, M. (2016). African media studies and marginality at the center. Black Camera, 7(2), 125-139. doi:10.2979/blackcamera.7.2.125

Aidoo, A. A. (1977). Our sister killjoy. Mississauga: Longman.

Asare, A. A. (2018). Truth without reconciliation: A human rights history of Ghana. Philadelphia: University of Pennsylvania Press.

Bakare- Yusuf, B. (2006). Fabricating identities: Survival and the imagination in Jamaican dancehall culture. Fashion Theory, 10(4), 461-483. doi:10.2752/136270406778664959

Benjamin, R. (2019). Race after technology: Abolitionist tools for the new Jim Code. Cambridge: Polity Press.

Bobo, J. (1995). Black women as cultural readers. New York: Columbia University.

Bobo, J. (Ed.) (2001). Black feminist cultural criticism. Oxford: Blackwell.

Bonsu, S. (2009). Colonial images in global times: consumer interpretations of Africa and Africans in advertising. Consumption, Markets \& Cultures 12(1), 1-25. doi: $10.1080 / 10253860802560789$

Boylorn, R.M. (2006). E pluribus unum (out of many, one). Qualitative Inquiry, 12(4), 651-680. 
AN AFRICAN CITY: BLACK WOMEN'S CREATIVITY

doi: $10.1177 / 1077800405282798$

Brown, A.M. (Ed.). (2019). Pleasure activism: The politics of feeling good. Chico, CA: AK Press.

Brown-Vincent, L. D. (2019). Seeing it for wearing it: Autoethnography as Black feminist methodology. Taboo: The Journal of Culture and Education 18(1), 109-125. doi: 10.31390/taboo.18.1.08

Bruggeman, D. (2017). Vlisco: Made in Holland, adorned in West Africa, (re)appropriated as Dutch design. Fashion, Style \& Popular Culture, 4(2), 197-214. doi: 10.1386/fspc.4.2.197_1

Bryan, B., Dadzie, S., \& Scafe, S. (1985). Heart of the race: Black women's lives in Britain. London: Virago.

Byrd, L. L., \& Tharps, A. D. (2002). Hair story: Untangling the roots of Black hair in America. New York: St Martin’s Griffin.

Campt, T. M. (2019). Black visuality and the practice of refusal. Women \& Performance: A Journal of Feminist Theory, 29(1), 79-87. doi:10.1080/0740770X.2019.1573625

Chakravartty, P., Kuo, R., Grubbs, V., \& McIlwain, C. (2018). \#CommunicationSoWhite. Journal of Communication, 68(2), 254-266. doi:10.1093/joc/jqy003

Chatman, D. (2015). Pregnancy, then it's "back to business": Beyoncé, black femininity, and the politics of a post-feminist gender regime. Feminist Media Studies, 15(6), 926-941. doi:10.1080/14680777.2015.1036901

Clark, M. (2014). To tweet our own cause: A mixed-methods study of the online phenomenon “Black Twitter.” Chapel Hill, NC: University of North Carolina at Chapel Hill Graduate School. doi:10.17615/7bfs-rp55 
AN AFRICAN CITY: BLACK WOMEN'S CREATIVITY

Coleman, R. M. (2011). “Roll up your sleeves!” Black women, black feminism in Feminist Media Studies. Feminist Media Studies, 11(1), 35-41. doi:

$10.1080 / 14680777.2011 .537023$

Collins, P. H. (2000). Black feminist thought: Knowledge, consciousness and the politics of empowerment. New York: Routledge.

Coly, A. A. (2015). Un/clothing African womanhood: colonial statements and postcolonial discourses of the African female body. Journal of Contemporary African Studies, 33(1), 12-26. doi:10.1080/02589001.2015.1021209

Coly, A. A. (2019). Postcolonial hauntologies: African women's discourses of the female body. Lincoln: University of Nebraska Press.

Cronberg, A. A. (2012). The story of Vlisco and real Dutch wax: From Helmond to Accra to Paris and back again. In R. Gerards \& S. M. Sho (Eds.), Vlisco fabrics (pp. 310-314). Arnhem: Artez.

Delhaye, C., \& Woets, R. (2015). The commodification of ethnicity: Vlisco fabrics and wax cloth fashion in Ghana. International Journal of Fashion Studies, 2(1), 77-98. doi: 10.1386/infs.2.1.77_1

Ford, T. C. (2015). Liberated threads: Black women, style, and the global politics of soul. Chapel Hill: University of North Carolina Press.

Gray, K. L. (2016). Race, gender, and virtual inequality: exploring the liberatory potential of Black cyberfeminist theory. In R.A. Lind (Ed.), Produsing theory in a digital world 2.0. (pp. 175-190). New York, Peter Lang.

Hall, K. M. Q. (2019). Naming a transnational Black feminist framework: Writing in darkness. Abingdon: Routledge. 
AN AFRICAN CITY: BLACK WOMEN'S CREATIVITY

hooks, b. (1992). Black looks: Race and representation. Boston: South End Press.

Jackson, S. J. (2014). Black celebrity, racial politics and the press: Framing dissent. New York: London.

Johnson, A. (2017). Getting comfortable to feel at home: clothing practices of Black Muslim women in Britain. Gender, Place \& Culture, 24(2), 274-287.

doi:10.1080/0966369X.2017.1298571

Jones, N. (2019). Dying to eat? Black food geographies of slow violence and resistance. ACME: An International Journal for Critical Geographies, 18(5), 1076-1099. Retrieved from https://acme-journal.org/index.php/acme/article/view/1683

Joseph, R. L. (2018). Postracial resistance: Black women, media, and the uses of strategic ambiguity. New York: New York University Press.

Lu, J. H., \& Steele, C. K. (2019). Joy is resistance: cross-platform resilience and (re)invention of Black oral culture online. Information, Communication \& Society, 22(6), 823-837. doi: 10.1080/1369118X.2019.1575449

Martin, A. L. Jr. (2019). Fandom while black: Misty Copeland, Black Panther, Tyler Perry and the contours of US black fandoms. International Journal of Cultural Studies, 22(6), 737753. doi:10.1177/1367877919854155

McKittrick, K. (2006). Demonic grounds: Black women and the cartographies of struggle. Minneapolis: University of Minnesota Press.

Mohammed, W. F. (2019). Online activism: Centering marginalized voices in activist work. Ada: A Journal of Gender, New Media \& Technology 15. Retrieved from https://adanewmedia.org/2019/02/issue15-mohammed/

Noble, S. (2018). Algorithms of oppression: How search engines reinforce racism. New York: 
AN AFRICAN CITY: BLACK WOMEN'S CREATIVITY

New York University Press.

Nyabola, N. (2014, January 2). Why do Western media get Africa wrong? Al Jazeera. Retrieved from https://www.aljazeera.com/indepth/opinion/2014/01/why-do-western-media-getafrica-wrong-20141152641935954.html

Nyabola, N. (2018a, March 13). Wakanda is not African, and that's OK. Al Jazeera. Retrieved from https://www.aljazeera.com/indepth/opinion/wakanda-african180313123713872.html

Nyabola, N. (2018b). Digital democracy, analogue politics: How the internet era is transforming politics in Kenya. London: ZED.

Ogunyankin, G. A. (2016). "These girls' fashion is sick!”: An African City and the geography of sartorial worldliness. Feminist Africa 21, 37-51. Retrieved from http://www.agi.ac.za/sites/default/files/image_tool/images/429/feminist_africa_journals/c urrent_issue/fa21_feature_3.pdf

Opoku-Mensah, A. (2010). Marching on: African feminist media studies. Feminist Media Studies, 1(1), 25-34. doi:10.1080/14680770120042792

Osei, K. (2019). Fashioning my garden of solace: A black feminist autoethnography. Fashion Theory, 23(6), 733-746. doi:10.1080/1362704X.2019.1657272

Salo, E., \& Mama, A. (2001). Talking about feminism in Africa. Agenda: Empowering Women for Gender Equity, 50(2001), 58-63. doi:10.1080/10130950.2001.9675993

Smith-Shomade, B. E. (2002). Shaded lives: African-American women and television. New Jersey: Rutgers University.

Sobande, F. (2017). Watching me watching you: Black women in Britain on YouTube. European Journal of Cultural Studies 20(6), 655-671. doi:10.1177/1367549417733001 
AN AFRICAN CITY: BLACK WOMEN'S CREATIVITY

Sobande, F. (2019). Woke-washing: "intersectional” femvertising and branding "woke" bravery. European Journal of Marketing. doi:10.1108/EJM-02-2019-0134

Sobande, F., Fearfull, A., \& Brownlie, D. (2019). Resisting media marginalisation: Black women's digital content and collectivity. Consumption, Markets \& Cultures.

doi:10.1080/10253866.2019.1571491

Steele, C.K. (2017). Black bloggers and their varied publics: The everyday politics of Black discourse online. Television and New Media 19(2), 112-127. doi: $10.1177 / 1527476417709535$

Sylvanus, N. (2013). Fashionability in colonial and postcolonial Togo. In K. Tranberg Hansen \& D. Soyini Madison (Eds.), African dress: Fashion, agency, performance (pp. 30-44). New York: Bloomsbury.

Tate, S. A. (2009). Black beauty: Aesthetics, stylization, politics. Abingdon: Ashgate.

Tulloch, C. (2016). The birth of cool: Style narratives of the African diaspora. London: Bloomsbury.

Warner, K. (2019). Value added: Reconsidering women-centered media and viewership: Guest editor's introduction. Communication, Culture \& Critique, 12(2), 167-172. doi: $10.1093 / \mathrm{ccc} / \mathrm{tcz} 023$

Williams, S. (2016). \#SayHerName: using digital activism to document violence against black women. Feminist Media Studies, 16(5), 922-925. doi:10.1080/14680777.2016.1213574

Young, Lola. (2000). What is Black British feminism? Women: A Cultural Review 11(1-2), 45-60. doi:10.1080/09574040050051415 